\title{
Effect of nutri-priming on germination indices and physiological characteristics of stevia seedling under salinity stress ${ }^{1}$
}

\author{
Mehdi Aghighi Shahverdi², Heshmat Omidi ${ }^{2}$, Seyed Jalal Tabatabaei
}

\begin{abstract}
Poor germination and low seedling growth of stevia (Stevia rebuadiana Bertoni) are common problems in the cultivation of the plant. On the other hand, salinity is one of the abiotic environmental stresses that reduce the performance of the product. The objective in this study was to assess the effect of nutri-priming with selenium (Se), iron (Fe) and boron (B) on stevia seed germination indices and physiological characteristics in sodium chloride $(\mathrm{NaCl})$ salinity condition $(0,30,60$ and $90 \mathrm{mM}$ ). Results indicated that the effect of salinity in nutri-priming were significant on germination percentage, germination rate, germination uniformity, germination value, seedling length, seedling vigor index, total chlorophyll, free proline content and enzymatic activity of catalase (CAT) and superoxide dismutase (SOD). Salinity stress decreased the percentage and rate of germination and seed vigor, however, nutri-priming reduces the adverse effects of salinity stress. Salinity also reduced the amount of chlorophyll content, in spite of all that this decrease was very low in terms of nutri-priming with $\mathrm{Se}, \mathrm{Se}+\mathrm{Fe}$ and $\mathrm{Se}+\mathrm{Fe}+\mathrm{B}$ in high salinity level $(90 \mathrm{mM})$. Salinity stress increased proline content and antioxidant enzyme activities of CAT and SOD, that nutri-priming especially with the Se more increased. The finding of this study leads to the conclusion that nutri-priming with nutrients, especially Se and Fe increased the antioxidant capacity of the plant to improve germination and seedling growth of stevia under salinity stress.
\end{abstract}

Index terms: antioxidant activity, chlorophyll, germination rate, germination uniformity, seed vigor.

\section{Efeito do amortecimento de nutrientes nos índices de germinação e nas características fisiológicas da plântula de stevia sob o estresse de salinidade}

\begin{abstract}
RESUMO - A má germinação e o baixo crescimento das mudas de stevia (Stevia rebuadiana Bertoni) são problemas comuns no cultivo da planta. Por outro lado, a salinidade é um dos estresses ambientais abióticos que reduzem o desempenho do produto. O objetivo deste estudo foi avaliar o efeito do selênio ( $\mathrm{Se}$ ), ferro (Fe) e boro (B) nos índices de germinação de sementes de stevia e características fisiológicas na condição de salinidade com cloreto de sódio $(\mathrm{NaCl})(0,30,60$ e $90 \mathrm{mM})$. Os resultados indicaram que o efeito da salinidade na nutrição foi significativo na porcentagem de germinação, na taxa de germinação, na uniformidade da germinação, no valor da germinação, no comprimento da plântula, no índice de vigor da plântula, clorofila total, teor de prolina livre e atividade enzimática da catalase (CAT) e superóxido dismutase (SOD). O estresse por salinidade diminuiu a porcentagem e a taxa de germinação e vigor de sementes, no entanto, o amortecimento de nutrientes reduz os efeitos adversos do estresse por salinidade. A salinidade também reduziu a quantidade de teor de clorofila, apesar de tudo isso, esta diminuição foi muito baixa em termos de nutrição com $\mathrm{Se}, \mathrm{Se}+\mathrm{Fe}$ e $\mathrm{Se}+\mathrm{Fe}+\mathrm{B}$ em alto nível de salinidade $(90 \mathrm{mM})$. O estresse de salinidade aumentou o conteúdo de prolina e as atividades de enzimas antioxidantes de CAT e SOD, que o cultivo de nutrientes especialmente com o Se aumentou. A descoberta deste estudo leva à conclusão de que especialmente $\mathrm{Se}$ e $\mathrm{Fe}$, aumentou a capacidade antioxidante da planta para melhorar a germinação e o crescimento de palmeiras da estevia sob o estresse de salinidade.
\end{abstract}

Termos de indexação: atividade antioxidante, clorofila, taxa de germinação, uniformidade de germinação, vigor de sementes.

\footnotetext{
${ }^{1}$ Submitted on 11/24/2016. Accepted for publication on 09/16/2017.

${ }^{2}$ Agricultural College and Medicinal Plant Research Center, Shahed University, P.O.Box 18151/159, Islamic Republic of Iran- Tehran.

*Corresponding author<omidi@shahed.ac.ir>
} 


\section{Introduction}

Stevia (Stevia rebaudiana Bertoni.), also known as a honey leaf, is a perennial plant belonging to the family Asteraceae and native to Paraguay (Kumar-Pal et al., 2013). The plant has a sweet taste due to the presence of diterpene Steviol glycosides (SV glys). Stevioside and Rebaudioside-A (Reb A) are dominant glycoside compositions of the plant which makes that plant to be even 300 times sweeter than sucrose (Hajihashemi and Ehsanpour, 2014). Because of self-incompatible flowers, the crossing is usually carried out by wind and insects (Raeeszadeh and Gharineh, 2014). Thus, the plant has low fertility percentage and hence low seed formation (Liopa-Tsakalidi et al., 2012) which limits its large-scale cultivation (Raji et al., 2015). However, self-compatibility is also reported by some researchers (Goettemoeller and Ching, 1999).

Salinity is one of the abiotic environmental stresses that seriously affect agricultural production across arid and semiarid environments (Nasri et al., 2014). Seed germination and seedling growth are the most sensitive stages of plant growth that strongly affected by salinity stress. Salinity stress decreased the germination percentage and germination rate in many plants (Yildirim et al., 2002).

Different species of plant indicate specific responses to abiotic stresses, because of this extensive research is done to discover the limits of tolerance during seed germination (Fernandez et al., 2016). In this regard, Jamil et al. (2005); Patade et al. (2011); Rouhi et al. (2011); Ansari and SharifZadeh (2012) stated that increasing salinity concentration causes reduced the germination percentage and seed germination time. Salinity to change the balance of plant hormones such as reducing hormones auxin, cytokinin, gibberellic acid and salicylic acid and increase abscisic acid and jasmonate in plant tissue, causes damage to seed germination via important factors such as reducing water availability, changes in domestic reserves seed mobility and impact on protein structures organized (Machado Neto et al., 2004; Ibrahim Ehab, 2016).

Seed priming is the known methods for rapid germination and sustained establishment of the plant in stress condition that the most influential factors on agricultural production (Bewley et al., 2013; Paparella et al., 2015). Different priming methods include hydro-priming, osmo-priming, halo-priming, thermo-priming and hormone-priming that different reports on different plants this priming are presented by researchers (Iqbal et al., 2012; Rehman et al., 2012; Mirshekari, 2015). One of the newest priming methods, using micro or macro nutrients for the seed treatment before sowing is called nutripriming (Rehman et al., 2012; Mirshekari, 2015).
In this regard, reported nutri-priming with commercial fertilizers to improve crop yield was one of the big benefits seed planting (Farooq et al., 2011). For example, rice seed priming with boric acid increases the yield and better seedling growth (Rehman et al., 2012). Reported that seed priming with the Se concentration of $5 \mathrm{mg}$ per liter will increase germination and seedling growth of the wheat plant (Yun et al., 1997). If could have a positive effect on seed germination due to antioxidant activity and glutathione-ascorbate cycle activity (Jezek et al., 2011). Dill seed priming with $\mathrm{Fe}$ and B elements have a significant effect on seed germination and seed vigor, so that seed priming with a solution of $1.5 \% \mathrm{Fe}$ and $1 \% \mathrm{~B}$ was reported a significant increase compared to control (Mirshekari, 2015).

Due to lack of micronutrients in soils of Iran (more than 49 percent of the soils of B and Fe deficiency) (Malakouti et al., 2009) and the importance of stevia that have the problem of poor germination and on the other hand the importance of nutrients, especially Se due to increased plant antioxidants under salinity stress condition, the objective in this study was to evaluate nutrient seed priming with $\mathrm{Fe}, \mathrm{B}$, and $\mathrm{Se}$ on germination indices and biochemistry characteristic under salt stress in herb stevia.

\section{Material and Methods}

\section{Seed collection}

Freshly matured seeds of stevia (Stevia rebaudiana Bertoni.) were collected in June 2015 from seed production fields in Firozabad Province (Iran, 34 $37^{\circ}{ }_{-} \mathrm{N}, 54^{\circ} 45^{\prime}$ E, $1790 \mathrm{~m} \mathrm{ASL}$ ). The mean seed dry weight per 100 seeds was $26.4 \pm 0.5 \mathrm{mg}$ and seed moisture ranged between $8 \%$ and $9 \%$. The seeds had no impurities and were stored in paper bags under $4{ }^{\circ} \mathrm{C}$ in darkness. Less than 2 months old seeds were used in the experiments.

\section{Nutri-priming and salt stress treatments}

To assess the effect of seed priming with $\mathrm{Fe}$ (source was Skustren 138), B (source was boric acid) and Se (source was sodium selenite) on germination indices and biochemical characteristics of seedling under salinity stress, was conducted a factorial experiment based on completely randomized design (CRD) with three replications at the Laboratory of Seed Science and Technology of Shahed University of Tehran in 2015. Experiment factors were salinity $(\mathrm{NaCl})$ stress $(0,30,60$ and 90 $\mathrm{mM}$ ) and nutri-priming in eight combinations, control (without priming), $\mathrm{Fe}, \mathrm{B}, \mathrm{Se}, \mathrm{B}+\mathrm{Fe}, \mathrm{Fe}+\mathrm{Se}, \mathrm{Se}+\mathrm{B}, \mathrm{Fe}+\mathrm{B}+\mathrm{Se}$.

\section{Germination tests}

Before conducting the experiment, in order to determine 
of best duration and concentration of priming with these three elements, was a pilot experiment, where five priming duration $(0,8,16,24$ and 32 hours) and five concentrations of nutrients $(0,0.5,1,1.5$ and $2 \%)$ for each nutrient separately, were tested. These results showed that the best duration and concentration were to seed priming with B 24 hours in concentration of $1.5 \%$, for Se 24 hours in concentration of $2 \%$ and for Fe concentration $1.5 \%$ in 24 hours, that was used this data in the experiment.

Stevia seeds sterilization with sodium hypochlorite (5\%) for 30 seconds and then washed with distilled water. At the end of priming, the seeds were washed with distilled water and air dried for 24 hours. In each Petri dish, 100 seeds were put on Whatman paper and based on various treatments was added each Petri dish $5 \mathrm{~mL}$ of distilled water (for control) or $\mathrm{NaCl}$ solution to the van't Hoff formula ( $\Psi=-\mathrm{MIRT}$; $\Psi$ : osmotic potential, according to Bar; M: molarity; I: Van ' $t$ Hoff factor $=$ 2 for $\mathrm{NaCl}$; R: constant number $=0.08206$ bar; T: temperature according to Kelvin) prepared (1.92, 3.84 and $5.76 \mathrm{~g} \mathrm{NaCl}$ per liter for 30,60 and $90 \mathrm{mM}$ respectively). Germination period was conducted in a growth chamber under controlled conditions with temperature of $23 \pm 2{ }^{\circ} \mathrm{C}, 16 / 8 \mathrm{~h} \mathrm{light/darkness} \mathrm{and} 70 \%$ relative humidity (Raina et al., 2013).

Germinated seeds were counted on the second day was done on a daily basis (Liopa-Tsakalidi et al., 2012) and finally at the end of testing period (11 days) was calculated germination percentage, germination rate, germination value, and vigor index according to formulas in Table 1. Also, germination uniformity was calculated using the Germin program (Soltani et al., 2001; Biradar et al., 2007; Pagter et al., 2009; Liopa-Tsakalidi et al., 2012).

\section{Antioxidant Enzymes Assay}

Samples were frozen in liquid nitrogen and stored at $-30^{\circ} \mathrm{C}$. One $\mathrm{g}$ of frozen sample was homogenized in a mortar with 5 $\mathrm{mL}$ of $50 \mathrm{mM}$ potassium phosphate buffer ( $\mathrm{pH}$ 7.5) containing 1 mM ethylenediaminetetraacetic acid (EDTA), $1 \mathrm{mM}$ dithiotreitol

Table 1. The computing relation of germination percentage (GP), germination rate (GR), germination value (GV) and seed vigor index (SVI) parameters studied in the experiment.

\begin{tabular}{ll}
\hline $\begin{array}{l}\text { Germination percentage } \\
\text { Germination rate }\end{array}$ & $\mathrm{GP}=(\mathrm{N} \times 100) / \mathrm{M}$ \\
$\begin{array}{l}\text { Germination value } \\
\text { Seed vigor index }\end{array}$ & $\mathrm{GV}=\mathrm{GP} \times \mathrm{MDG}$ \\
\hline $\mathrm{N}=$ sum of germinated seeds at the end of the experiment, $\mathrm{M}=$ total planted \\
seeds, Ti = number of days after germination, $\mathrm{SL}=$ Seedling Length.
\end{tabular}

and $2 \%$ polyvinyl pyrrolidone (PVP). The homogenate was centrifuged at 15,000 $\mathrm{g}$ for $25 \mathrm{~min}$ and the supernatant was used for antioxidant enzyme assay.

\section{Superoxide Dismutase (SOD) Assay}

For superoxide dismutase (SOD) activity measurement, the method of Beauchamp and Fridovich (1971) was used which is briefly described here. About $3 \mathrm{~mL}$ of reaction mixture, containing $0.1 \mathrm{~mL}$ of $200 \mathrm{mM}$ methionine, $0.01 \mathrm{~mL}$ of $2.25 \mathrm{mM}$ nitro blue tetrazolium (NBT), $0.1 \mathrm{~mL}$ of $3 \mathrm{mM}$ EDTA, $1.5 \mathrm{~mL}$ of $100 \mathrm{mM}$ potassium phosphate buffer, 1 $\mathrm{mL}$ distilled water and $0.05 \mathrm{~mL}$ of enzyme extraction, were taken in test tubes in duplicate from each enzyme sample. Two tubes without enzyme extract were taken as control. The reaction was started by adding $0.1 \mathrm{~mL}$ riboflavin $(60 \mu \mathrm{M})$ and placing the tubes below a light source of two $15 \mathrm{~W}$ fluorescent lamps for $15 \mathrm{~min}$. The reaction was stopped by switching off the light and covering the tubes with black cloth. Absorbance was recorded at $560 \mathrm{~nm}$.

\section{Catalase (CAT) Assay}

The catalase activity assay was performed using Chance and Maehly (1995) method. Three $\mathrm{mL}$ reaction mixture containing $2.5 \mathrm{~mL} 0.05 \mathrm{mM}$ sodium phosphate buffer $(\mathrm{pH}=7), 30 \mu \mathrm{g}$ protein solution was added to quettes and at the time of measurement, $30 \mu \mathrm{L} 30 \% \mathrm{H}_{2} \mathrm{O}_{2}$ was added to reaction mixture and the absorbance at $240 \mathrm{~nm}$, at $60 \mathrm{sec}$, and at $25^{\circ} \mathrm{C}$ was recorded spectrophotometrically. The control contained $2.5 \mathrm{~mL}$ sodium phosphate buffer and $30 \mu \mathrm{g}$ protein. Catalase activity was reported based on absorption alternations per $\mathrm{mg}$ protein per min.

\section{Proline Assay}

Proline was determined according to the method described by Bates et al. (1973). Approximately $0.5 \mathrm{~g}$ of fresh leaf material was homogenized in $10 \mathrm{~mL}$ of $3 \%$ aqueous sulfosalicylic acid. Then, this aqueous solution was filtered through Whatman's paper No. 2 and finally, $2 \mathrm{~mL}$ of filtrated solution was mixed with $2 \mathrm{~mL}$ acid-ninhydrin and $2 \mathrm{~mL}$ of glacial acetic acid in a test tube. The mixture was placed in a water bath for $1 \mathrm{~h}$ at $100^{\circ} \mathrm{C}$. The reaction mixture was extracted with $4 \mathrm{~mL}$ toluene, cooled to room temperature, and the absorbance was measured at $520 \mathrm{~nm}$ with a spectrometer.

\section{Statistical Analysis}

After normalization test, the data were analyzed by SAS 9.2 (SAS Institute, Cary, NC, USA). Means were compared with LSD in SAS at 5\% statistical probability levels. 


\section{Results and Discussion}

\section{Germination percentage}

The results showed the effect of salinity, nutri-priming and interaction of these two factors (salinity $\times$ priming) was significant on stevia seed germination percentage (Table 2). The highest germination percentage was in terms of without salinity in priming by $\mathrm{Fe}+\mathrm{B}$ (with an average of $58.66 \%$ ) (Table 3). Germination percentage in higher salinity levels $(90 \mathrm{mM})$ in terms of priming with Se and B + Fe showed any

Table 2. Analysis of variance for effect of nutri-priming and salinity on stevia seed germination indices.

\begin{tabular}{lrrrrrrr}
\hline \multirow{2}{*}{ Sources of variance } & \multicolumn{9}{c}{ Mean square (MS) } \\
\cline { 2 - 7 } & DF & GP & GR & GU & GV & SL & SVI \\
\hline Salinity (S) & 3 & $512.66^{* *}$ & $43.69^{* *}$ & $1.43^{* *}$ & $2.92^{* *}$ & $4.99^{* *}$ & $47648662.3^{* *}$ \\
Nutri-priming (NP) & 7 & $175.52^{* *}$ & $1.29^{* *}$ & $0.50^{\text {ns }}$ & $1.09^{* *}$ & $0.77^{* *}$ & $4604291.3^{* *}$ \\
NP $\times$ S & 21 & $125.74^{* *}$ & $1.54^{* *}$ & $0.89^{*}$ & $0.80^{* *}$ & $0.66^{* *}$ & $1499660.9^{* *}$ \\
Experimental error & 64 & 18.00 & 0.20 & 0.32 & 0.13 & 0.011 & 424428.3 \\
Coefficient of Variation (\%) & - & 9.51 & 13.92 & 15.21 & 19.52 & 16.57 & 21.63 \\
\hline
\end{tabular}

ns, $*$ and $* *$ non-significant, Significant at $5 \%$ and $1 \%$ respectively.

(GP: Germination Percentage, GR: Germination Rate, GU: Germination Uniformity, GV: Germination Value, SL: Seedling Length, SVI: Seedling Vigor Index).

Table 3. Mean comparison of stevia seed germination indices under effect of different nutri-priming and salinity interaction.

\begin{tabular}{|c|c|c|c|c|c|c|c|}
\hline \multicolumn{2}{|c|}{ Treatment } & \multirow{2}{*}{$\begin{array}{l}\text { GP } \\
(\%)\end{array}$} & \multirow{2}{*}{$\begin{array}{c}\text { GR } \\
\text { (seed per day) }\end{array}$} & \multirow{2}{*}{ GU } & \multirow{2}{*}{ GV } & \multirow{2}{*}{$\begin{array}{c}\mathrm{SL} \\
(\mathrm{cm})\end{array}$} & \multirow{2}{*}{ SVI } \\
\hline Salinity (mM) & Nutri-priming & & & & & & \\
\hline \multirow{8}{*}{0 (control) } & Control & 38.66 g..k & $2.76 \mathrm{f} . . \mathrm{i}$ & 3.71 a..f & 1.36 h..k & $.085 \mathrm{bcd}$ & 3306.7 d..g \\
\hline & $\mathrm{Fe}$ & $40.00 \mathrm{f} . . \mathrm{j}$ & 3.79 cde & $2.90 \mathrm{ef}$ & $1.45 \mathrm{~g} . . \mathrm{k}$ & $0.87 \mathrm{bcd}$ & 3493.3 c..f \\
\hline & $\mathrm{B}$ & 38.66 g...k & $4.43 \mathrm{bc}$ & 3.26 c..f & 1.37 h..k & $0.73 \mathrm{cde}$ & $2825.3 \mathrm{~d} . . \mathrm{h}$ \\
\hline & $\mathrm{Se}$ & 46.66 b..g & $5.87 \mathrm{a}$ & $2.83 \mathrm{f}$ & 1.99 b..h & $1.21 \mathrm{a}$ & $5664.3 \mathrm{ab}$ \\
\hline & $\mathrm{Fe}+\mathrm{B}$ & $58.66 \mathrm{a}$ & $6.23 \mathrm{a}$ & 3.47 b..f & $3.13 \mathrm{a}$ & $1.02 \mathrm{~b}$ & $6013.3 \mathrm{a}$ \\
\hline & $\mathrm{Se}+\mathrm{B}$ & 50.66 a..d & $5.56 \mathrm{a}$ & 3.96 a..f & 2.33 b..e & $0.75 \mathrm{cde}$ & $3797.3 \mathrm{cde}$ \\
\hline & $\mathrm{Fe}+\mathrm{Se}$ & 42.66 d..j & $4.71 \mathrm{~b}$ & 3.27 c..f & 1.65 e..j & $0.90 \mathrm{bc}$ & $3873.3 \mathrm{~cd}$ \\
\hline & $\mathrm{Fe}+\mathrm{B}+\mathrm{Se}$ & $52.00 \mathrm{abc}$ & $5.98 \mathrm{a}$ & 3.65 a..f & 2.45 a..d & $1.00 \mathrm{~b}$ & $5200.0 \mathrm{ab}$ \\
\hline \multirow{8}{*}{30} & Control & $52.00 \mathrm{abc}$ & $4.13 \mathrm{bcd}$ & 4.15 a..d & $2.48 \mathrm{abc}$ & $0.90 \mathrm{bc}$ & $4648.0 \mathrm{bc}$ \\
\hline & $\mathrm{Fe}$ & $53.33 \mathrm{ab}$ & $4.40 \mathrm{bc}$ & $4.69 \mathrm{a}$ & $2.58 \mathrm{abc}$ & $1.01 \mathrm{~b}$ & $5413.3 \mathrm{ab}$ \\
\hline & B & 49.33 b..e & 3.65 cde & 3.61 a..f & 2.23 b..f & $0.69 \mathrm{def}$ & 3505 c..f \\
\hline & $\mathrm{Se}$ & $52.00 \mathrm{abc}$ & $3.48 \mathrm{def}$ & 3.53 b..f & $2.49 \mathrm{abc}$ & $0.97 \mathrm{~b}$ & $5159.3 \mathrm{ab}$ \\
\hline & $\mathrm{Fe}+\mathrm{B}$ & 48.00 b..f & $3.45 \mathrm{def}$ & 3.59 a..f & 2.10 b..g & $0.95 \mathrm{~b}$ & $4628.0 \mathrm{bc}$ \\
\hline & $\mathrm{Se}+\mathrm{B}$ & 48.00 b..f & $3.29 \mathrm{efg}$ & 3.83 a..f & 2.09 b..g & 0.56 e..i & 2712.0 d..i \\
\hline & $\mathrm{Fe}+\mathrm{Se}$ & 45.33 b..h & 3.03 e..h & 3.86 a..f & 1.87 c..i & 0.58 e..h & 2660.0 d..j \\
\hline & $\mathrm{Fe}+\mathrm{B}+\mathrm{Se}$ & $52.00 \mathrm{abc}$ & 3.65 cde & 3.86 a..f & $2.48 \mathrm{abc}$ & $0.73 \mathrm{cde}$ & $3824.0 \mathrm{~cd}$ \\
\hline \multirow{8}{*}{60} & Control & 46.66 b..g & 2.46 h..j & 3.81 a..f & 1.99 b..h & 0.58 e..i & 2701.3 d..i \\
\hline & $\mathrm{Fe}$ & 50.66 a..d & 2.69 f..i & 3.61 a..f & 2.33 b..e & 0.64 efg & 3234.7 d..g \\
\hline & B & 38.66 g...k & $2.16 \mathrm{ijk}$ & 3.71 a..f & 1.36 h..k & 0.39 h..1 & 1513.3 i... \\
\hline & $\mathrm{Se}$ & 50.33 a.d & 2.33 h..k & 3.70 a..f & 1.57 f..j & 0.52 f..j & 2648.8 d..j \\
\hline & $\mathrm{Fe}+\mathrm{B}$ & 50.33 a..d & 2.20 h..k & 3.60 a..f & $1.27 \mathrm{ijk}$ & $0.68 \mathrm{~d} . . \mathrm{g}$ & 3451.6 c..f \\
\hline & $\mathrm{Se}+\mathrm{B}$ & 48.00 b..f & $2.65 \mathrm{f} . . \mathrm{i}$ & $4.42 \mathrm{ab}$ & 2.10 b..g & $0.50 \mathrm{f} . . \mathrm{j}$ & $2455.1 \mathrm{f} . . \mathrm{j}$ \\
\hline & $\mathrm{Fe}+\mathrm{Se}$ & 40.00 f..j & 2.25 h..k & $4.41 \mathrm{abc}$ & 1.46 h..k & 0.47 g..k & 1911.1 h..k \\
\hline & $\mathrm{Fe}+\mathrm{B}+\mathrm{Se}$ & 44.00 c..i & $2.68 \mathrm{f} . . \mathrm{i}$ & 4.03 a..e & $1.76 \mathrm{~d} . . \mathrm{j}$ & 0.56 e..i & $2493.3 \mathrm{f..j}$ \\
\hline \multirow{8}{*}{90} & Control & $36.00 \mathrm{ijk}$ & $1.76 \mathrm{ijk}$ & 3.36 b..f & $1.20 \mathrm{i} . .1$ & 0.251 & $956.7 \mathrm{kl}$ \\
\hline & $\mathrm{Fe}$ & 46.66 b..g & $2.15 \mathrm{ijk}$ & 3.45 b..f & 1.99 b..h & $0.35 \mathrm{jkl}$ & 1620.0 h..1 \\
\hline & B & 25.331 & 1.141 & $3.16 \mathrm{def}$ & 0.581 & 0.261 & 666.71 \\
\hline & $\mathrm{Se}$ & 50.66 a..d & 2.41 h..k & 3.91 a..f & 2.33 b..e & 0.37 h... & 1925.3 h..k \\
\hline & $\mathrm{Fe}+\mathrm{B}$ & $53.33 \mathrm{ab}$ & $2.70 \mathrm{f} . . \mathrm{i}$ & 3.83 a..f & $2.62 \mathrm{ab}$ & $0.37 \mathrm{i} . .1$ & 1978.7 h..k \\
\hline & $\mathrm{Se}+\mathrm{B}$ & $34.66 \mathrm{jk}$ & $1.61 \mathrm{ijk}$ & 3.97 a..f & $1.09 \mathrm{jkl}$ & $0.30 \mathrm{kl}$ & $1033.3 \mathrm{kl}$ \\
\hline & $\mathrm{Fe}+\mathrm{Se}$ & $34.66 \mathrm{jk}$ & $1.75 \mathrm{ijk}$ & 4.06 a..d & $1.10 \mathrm{jkl}$ & 0.41 h..1 & $1422.2 \mathrm{jkl}$ \\
\hline & $\mathrm{Fe}+\mathrm{B}+\mathrm{Se}$ & $30.66 \mathrm{kl}$ & $1.55 \mathrm{kl}$ & 3.73 a..e & $0.85 \mathrm{kl}$ & $0.31 \mathrm{jkl}$ & $973.3 \mathrm{kl}$ \\
\hline
\end{tabular}

In each column, means having at least one same letter, are not significantly different according to LSD test $(\mathrm{p} \leq 0.05)$. 
significant difference, and priming reduces the adverse effect of salinity on seed germination. Seed priming with $\mathrm{Se}$ and $\mathrm{Fe}+\mathrm{B}$ caused germination increases (14.66 and $17.33 \%$ respectively) in salinity levels $90 \mathrm{mM}$ was compared to the control (Table 3).

\section{Germination rate}

Germination rate of stevia seed was affected by salinity, nutri-priming and interaction of salinity $\times$ nutripriming (Table 2). Priming with $\mathrm{Se}, \mathrm{Fe}+\mathrm{B}, \mathrm{Se}+\mathrm{B}$ and $\mathrm{Fe}+\mathrm{B}+\mathrm{Se}$ in without salinity (control) had highest germination rate (respectively 5.87, 6.23, 5.56 and 5.98 seeds per day) (Table 3).

\section{Germination uniformity}

Effect of salinity, nutri-priming and interaction of salinity and nutri-priming were significant on germination uniformity (Table 2). The lowest germination uniformity in priming with Se in control levels of salinity respectively but the highest this trait was achieved in many treatments at each salinity stress level (Table 3).

\section{Seedling length}

Salinity, nutri-priming, and interaction between the two (salinity $\times$ nutri-priming) was a significant effect on seedling length (Table 2). The greatest seedling length was in control salinity level under the condition of priming with Se and the shortest seedling length was achieved at the highest levels of salinity $(90 \mathrm{mM})$ in terms of non-priming (Table 3 ).

\section{Seedling vigor index}

Seedling vigor index was affected by salinity, nutripriming and interaction between the two treatments were used (Table 2). So that maximum seedling vigor index achieved in priming combined of $\mathrm{Se}, \mathrm{Fe}+\mathrm{B}$, and $\mathrm{Fe}+\mathrm{B}+\mathrm{Se}$ in control salinity level, also, priming combined $\mathrm{Fe}$ and $\mathrm{Se}$ in $30 \mathrm{mM}$ salinity level, which compared with control causes increased $71.29,81.85,57.25,16.46$, and $11 \%$, respectively (Table 3 ).

\section{Total chlorophyll content}

Effect of salinity, nutri-priming and interaction between was significant on the amount of total chlorophyll $(\mathrm{p} \leq 0.01)$ (Table 4). With increasing salinity levels was observed a significant decrease in the total chlorophyll. The highest amount of chlorophyll in the combination of three elements (Fe, B, and Se) and the combination of Se and B, at the level of control Salinity (respectively 0.21 and $0.20 \mu \mathrm{g} / \mathrm{mg} \mathrm{FW}$ ) (Figure 1). Seed priming with B and especially Se in 60 and $90 \mathrm{mM}$ salinity levels increased the total chlorophyll content was compared without priming, this increases the amount of total chlorophyll in priming by Se alone showed an increase of about $41.66 \%$ compared to control treatment (Figure 1).

\section{Free proline content}

Effect of Salinity $(p \leq 0.05)$, nutri-priming $(p \leq 0.01)$ and the interaction of these two $(p \leq 0.05)$ was significant on free proline content (Table 4). Increasing salinity levels caused significantly increased of proline content. The highest free proline content in nutri-priming $(\mathrm{Fe}+\mathrm{B}+\mathrm{Se})$ in the salinity of $90 \mathrm{mM}$ with an average $538.4 \mu \mathrm{mol} / \mathrm{g} \mathrm{FW}$, respectively (Figure 2).

\section{Catalase activity}

According to results of analysis of variance, the effects of salinity, nutri-priming and salinity $\times$ nutri-priming was significant on catalase activity $(p \leq 0.01)$ (Table 4$)$. Salinity stress caused increased catalase activity at all levels of nutri-priming, so that the highest enzyme activity achieved in the salinity stress of $90 \mathrm{mM}$ in priming stevia seeds with a combination of nutrients (Fe, B, Se) and compound (Fe and Se) 340.1 and $333.5 \mu \mathrm{mol} / \mathrm{g}$ FW respectively (Figure 3 ). With increasing salinity stress is more evident, nutrients role of seed priming with high levels of salinity stress $(60$ and $90 \mathrm{mM})$.

\section{Superoxide dismutase activity}

The results showed that the effect of salinity stress, nutripriming and interaction of salinity stress in nutri-priming was

Table 4. Analysis of variance for effect of nutri-priming and salinity on physiological traits of stevia seedling.

\begin{tabular}{cccccc}
\hline \multirow{2}{*}{ Sources of variance } & \multicolumn{5}{c}{ Mean square } \\
\cline { 2 - 5 } & DF & Total Chl & Proline & CAT & SOD \\
\hline Salinity (S) & 3 & $26.28^{* *}$ & $0.21^{*}$ & $0.403^{* *}$ & $409.32^{* *}$ \\
Nutri-priming (NP) & 7 & $21.37^{* *}$ & $0.37^{* *}$ & $0.117^{* *}$ & $206.34^{* *}$ \\
NP $\times$ S & 21 & $25.45^{* *}$ & $0.22^{*}$ & $0.008^{* *}$ & $4.80^{* *}$ \\
Experimental error & 64 & 7.18 & 0.08 & 0.0001 & 1.20 \\
Coefficient of Variation (\%) & - & 13.10 & 8.50 & 7.75 & 5.57 \\
\hline
\end{tabular}

ns, * and ** respectively non-significant, Significant at $5 \%$ and $1 \%$.

(Chl: Chlorophyll, CAT: Catalase activity, SOD: Superoxide dismutase activity). 


\section{-Control $\square 30 \mathrm{mM} \quad \square 60 \mathrm{mM} \quad \square 90 \mathrm{mM}$}

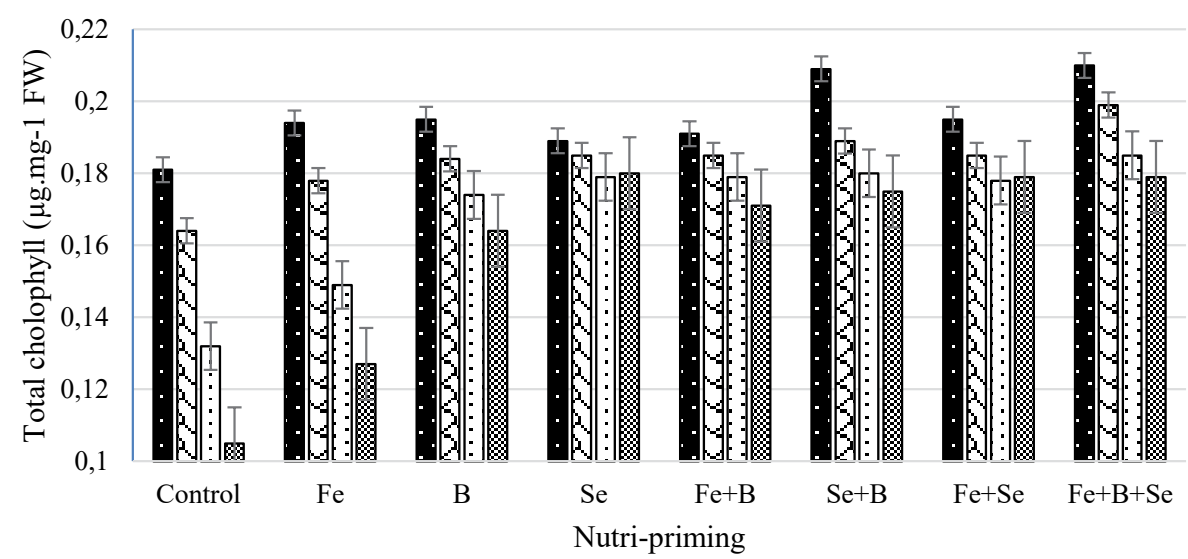

Figure 1. Comparison of mean, interaction effect of salinity stress in nutri-priming on total chlorophyll content.

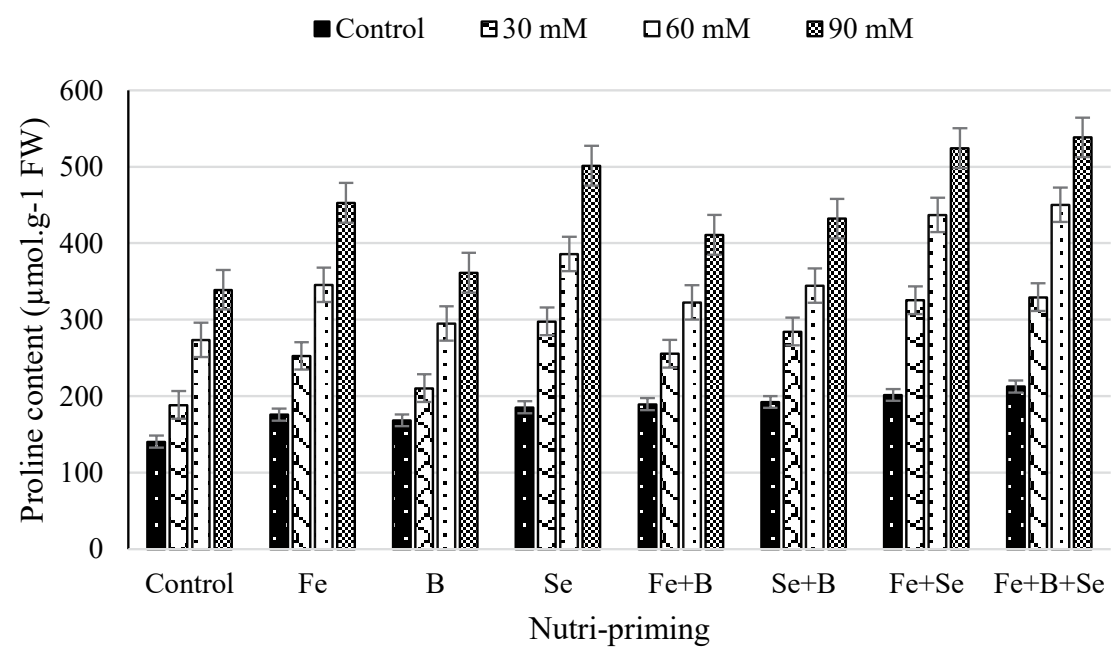

Figure 2. Comparison of mean, interaction effect of salinity stress in nutri-priming on proline content.

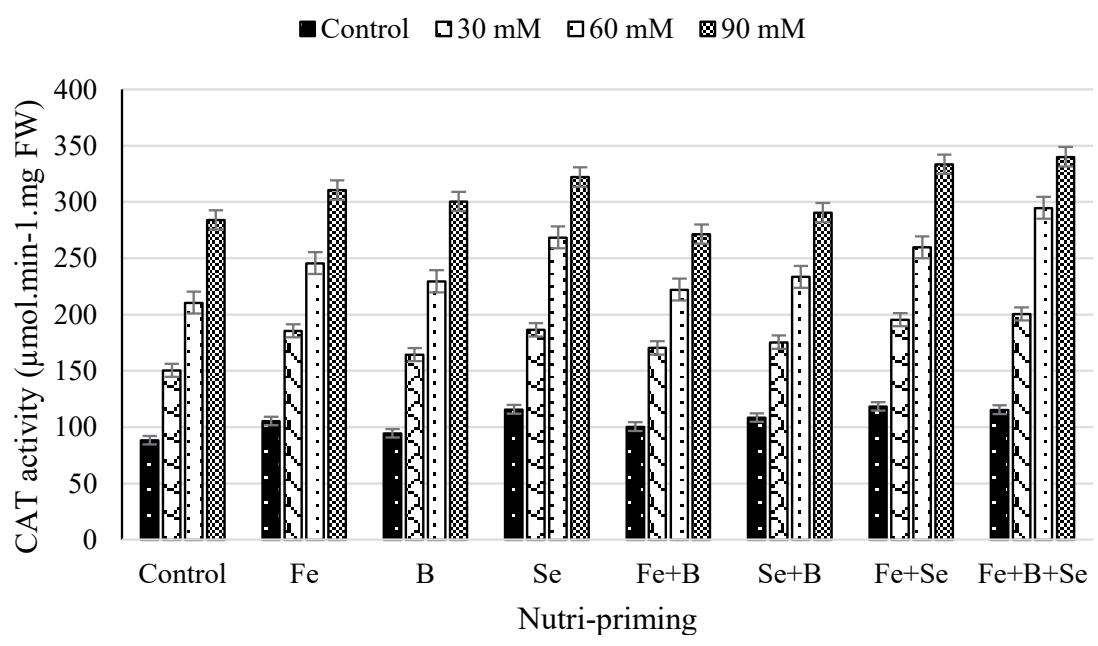

Figure 3. Comparison of mean, interaction effect of salinity stress in nutri-priming on CAT activity. 
significant on superoxide dismutase (Table 4). An increase with increasing salinity levels was observed in the activity of superoxide dismutase so that the most activity of this enzyme was in a combination of salinity stress $90 \mathrm{mM}$ in nutri-priming with a combination of three elements $(\mathrm{Fe}+\mathrm{B}+\mathrm{Se})(475 \mu \mathrm{mol} / \mathrm{g} \mathrm{FW})$.

\section{Discussion}

One of purpose this study was to evaluate the effect of salinity on seed germination and physiological indices Stevia seedlings, that the results showed salinity have adverse effects on germination indices and reduced the percentage and rate of germination, seedling length, and seed vigor index (Table 3). More other researchers also reported the deleterious effects of salinity $(\mathrm{NaCl})$ on seed germinability and seedling growth of many crops. The reasons of reduced germination percentage can be attributed to primary water uptake reduction and the adverse effect of osmotic potential and ion toxicity on physiological processes of seed germination (Tabatabaei, 2006; Javadi et al., 2015). In between the different levels of salinity stress, a small increase in compared to the control (without salinity stress), caused increase seed germination percentage. The reason for this may be due to the stimulatory effect of sodium chloride, which has the effect of stimulating out of root in seed and increases the germination percentage at low concentration of salt. Matias et al. (2015) reported seed priming more efficient to improve the performance of cucumber seedling in bio-saline water.

On the other hand, seed priming with nutrients (nutripriming) have two beneficial effect, firstly caused will increase germination components (percentage and rate of germination and seed vigor) and secondly, moderate the adverse effects of salinity stress due to sodium chloride, that between priming compound, $\mathrm{Se}, \mathrm{Fe}$ and $\mathrm{B}$ compound and also the composition of $\mathrm{Fe}, \mathrm{B}$ and $\mathrm{Se}$ had more positive effects on germination indices (Table 3). Priming enhanced seed performances are related to the repair and the buildup of nucleic acid, enhanced synthesis of protein, repair of membranes and improves the antioxidant system (McDonald, 2000; Hsu et al., 2003). The beneficial effects of priming with nutrients have been successfully reported by various scientists in various crops (Shah et al., 2011; Aboutalebian et al., 2012; Mirshekari et al., 2015; Rehman et al., 2012). Seedling vigor index is important for rapid stand establishment and early growth of the plants as reported by Tabrizian and Osareh (2007).

In this study, the results showed that seed priming with $\mathrm{Fe}$ and $\mathrm{B}$ compound in control salinity level had the highest seed vigor index, that priming with selenium at 0 and $30 \mathrm{mM}$ levels of salinity and the combination of three elements together in without salinity were also in the same group statistical. Several researchers also reported the positive effects of priming with $\mathrm{Fe}$ and $\mathrm{B}$ combines in seeds germination indices of different plants (Mirshekari, 2015; Memon et al., 2013). Increasing seed vigor indexes as a result of priming with nutrient can result in a significant increase in length and weight seedling and seed germination (the two parameters involved in the calculation of seed vigor), that may be are because the role of these elements in cell division and cell elongation or cell division and growth meristematic (Mouhtaridou et al., 2004; Khan et al., 2006; Memon et al., 2013). Priming the seeds with micronutrients makes them able to rapidly imbibe water and revive metabolism and germination, and as results in a higher rate germination percentage, improved establishment seedling and increased stress tolerance (Mirshekari, 2015).

Salinity stress in this experiment caused reduces of total chlorophyll content and increased of proline content and activity of antioxidant enzymes CAT and SOD. However priming with nutrients, causing moderated the adverse effect of salinity stress on biochemical characteristics of the stevia seedling, so that reduction of the amount of total chlorophyll was minor in terms of priming with nutrients in high salinity stress conditions (Figure 1). Priming with elements of $\mathrm{Se}, \mathrm{Fe}$ $+\mathrm{Se}$ and $\mathrm{Fe}+\mathrm{Se}+\mathrm{B}$ in comparison with the control without priming at the highest levels of salinity $(90 \mathrm{mM})$ increased almost $70 \%$ of the total chlorophyll seedling (Figure 1). Increasing the amount of chlorophyll thus seed priming with nutrients is stated in different reports (Mouhtaridou et al., 2004; Rehman et al., 2012; Memon et al., 2013). Salinity stress and priming with nutrients caused increases free proline content in seedling were compared with the control (without priming) (Figure 2). Changes proline content with a variety priming of nutrients in without salinity stress condition, so are not significant, but when salinity stress, proline content fluctuations are very high in condition applying priming with nutrient. In between treatments, priming with Se alone and in combination with $\mathrm{Fe}$ and with $\mathrm{Fe}$ and $\mathrm{B}$ showed maximum proline in high salinity stress.

Javadi et al. (2015) concluded that proline acts as a signaling/regulatory molecule and in the case of salt stress will be able to enhance the resistance of the plant to salinity. Zhang et al. (2006) reported that there is a positive relationship between proline accumulation and the antioxidant level in the plant that the free radicals (ROS) caused by stress increases and leads to accumulation of free proline in the plant. It seems $\mathrm{Se}$ and $\mathrm{Fe}$ by increasing the activity of the enzyme proline 5 -carboxylase synthase, as a key enzyme in the synthesis of proline increased synthesis of these secondary metabolites in 


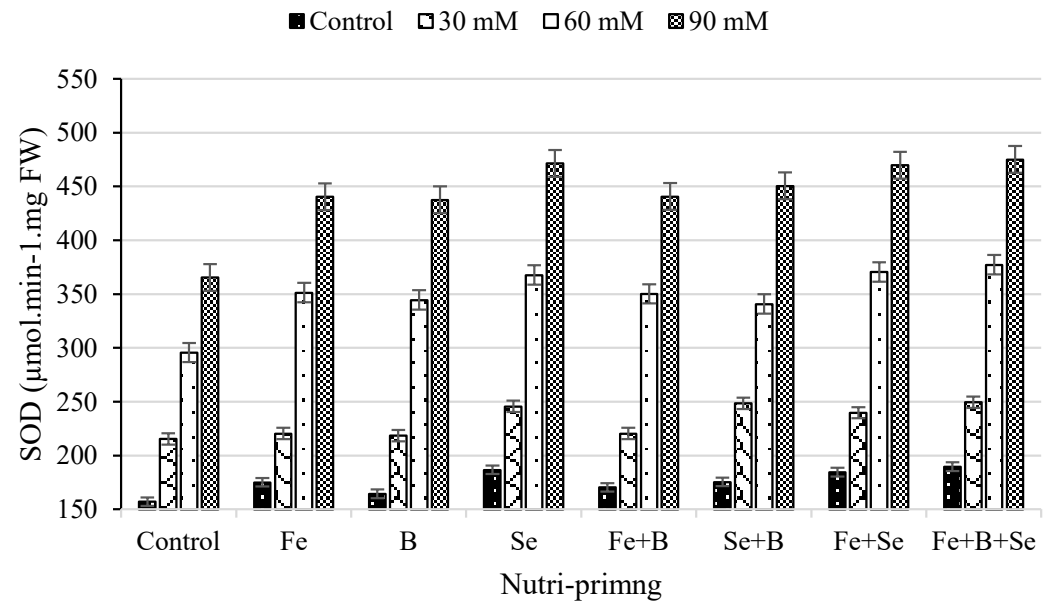

Figure 4. Comparison of mean, interaction effect of salinity stress in nutri-priming on SOD activity.

conditions of high salinity (Javadi et al., 2015).

The antioxidant activity of catalase and superoxide dismutase increased under salt stress (Figures 3 and 4) that the answer is crop tolerance to salinity conditions (LinDai et al., 2009; Wang et al., 2013). Salinity increases the activity of antioxidant enzymes CAT and SOD were all priming treatments. Se due to having antioxidizing and anticancer properties of such as micronutrients it's the addition role in increasing the tolerance of plants to adverse effects of environmental also plays a significant role in maintaining human health (Khaliq et al., 2015). Rice seed priming with Se increased the activity of antioxidants such as SOD, CAT, POD (Khaliq et al., 2015).

Metabolic activities are expected to increase remarkably in seeds following their priming that may lead to higher activity of reactive oxygen species (ROS) as secondary products of mitochondrial respiration. There is strong evidence that peroxides and free radicals are abundantly produced within seeds during germination (Bailly, 2002), and are cooperatively tackled by enzymatic reactions (Farooq et al., 2009). The enhanced expression and activity of antioxidant enzymes as recorded in our studies has been proposed as part of seed strategy to cope with ROS produced during seed priming (Chiu et al., 2005). The Se has been ascribed as a natural stimulant of antioxidant activity in plants (Germ et al., 2007). The drop in various emergence, seedling growth, and biochemical attributes observed at an elevated Se concentration may be due to an inverse relation between solute concentration and soaking time as proposed earlier (Farooq et al., 2009). Although no evidence for direct involvement of Se in promoting plant cell division is available, it is known to favor plant growth at lower concentrations (Germ et al., 2007). Selenium through changes activities of antioxidant enzymes can affect on germination and physiological processes and through affect on germination rate caused improved seedling establishment. The positive effect of Se on seed germination is concerned to increase the antioxidant activity of glutathione peroxidase and activate glutathioneascorbate cycle (Sajedi, 2015).

\section{Conclusions}

The finding of this study leads to the conclusion that priming with nutrients, especially $\mathrm{Fe}$ and $\mathrm{Se}$ through increasing the amount of seedlings chlorophyll and proline were improved seedling growth indices. Salinity stress reducing the effect on germination indices, but nutri-priming with increase the amount of minerals in the seed and by reducing the mean time required for germination increased the percentage and rate germination as well as the negative effects of stress-induced sodium chloride also modified with increased antioxidant activity of the enzyme.

\section{References}

ABOUTALEBIAN, M.A.; EKBATANI, G.Z.; SEPHEHRI, A. Effects of on-farm seed priming with zinc sulfate and urea solutions on emergence properties, yield and yield components of three rainfed wheat cultivars. Annals Biological Research, v.3, p.4790-4796, 2012. https://profs.basu.ac.ir/abutalebian/upload_file/art.5905.pdf.

ANSARI, O.; SHARIF-ZADEH, F. Osmo and hydropriming improvement germination characteristics and enzyme activity of Mountain Rye (Secale montanum) seeds under drought stress. Journal of Stress Physiology \& Biochemistry, v.8, p.253-61, 2012. www.jspb.ru/issues/2012/N4/JSPB 2012_4_253-261.pdf.

BAILLY, C. Active oxygen species, and antioxidants in seed biology. Seed Science Research, v.14, p.93-107, 2002. DOI: https://doi. org/10.1079/SSR2004159. 
BATES, L.; WALDREN, R.; TEARE, I. Rapid determination of free proline for water-stress studies. Plant and Soil, v.39, p.205-207, 1973. link.springer.com/article/10.1007/BF00018060

BEAUCHAMP, C.; FRIDOVICH, I. Superoxide Dismutase: Improved assays and an assay applicable to acrylamide gels. Analytical Biochemistry, v.44, p.276-287, 1971. www. sciencedirect.com/science/article/pii/0003269771903708

BEWLEY, J.D.; BRADFORD, K.J.; HILHORST, H.W.M.; NONGAKI, H. Seed's physiology of development. In: Germination and dormancy. 3.ed. New York: Springer; 2013. 392p.

BIRADAR, K.S.; SALIMATH, P.M.; RAVIKUMAR, R.L. Genetic variability for seedling vigor, yield and yield components in local germplasm collections of Greengram (Vigna radiata (L.) wilczek). Karnataka Journal Agriculture Science, v.20, n.3, p.608-609, 2007. 14.139.155.167/test5/index.php/kjas/article/view/935/928

CHANCE, B.; MAEHLY, A.C. Assay of catalase and peroxidase. New York, NY: Academic Press, 1995.p. 764-775.

CHIU, K.Y.; CHEN, C.L.; SUNG, J.M. Why low temperature primed sh-2 sweet corn seeds have better storability: some physiological clues. Seed Science Technology, v.33, p.199-213, 2005. www.ingentaconnect. $\mathrm{com} /$ content/ista/sst/2005/00000033/00000001/art00020

FAROOQ, M.; BASRA, S.M.A.; WAHID, A.; KHALIQ, A.; KOBAYASHI, N. Rice seed invigoration: a review. In: LICHTFOUSE, E. (ed). Organic farming, pest control and remediation of soil pollutants: sustainable agricultural reviews. Springer Science, v.1, p.137-175, 2009. www.springer.com/la/book/9781402096532

FAROOQ, M.; REHMAN, A.; AZIZ, T.; HABIB, M. Boron nutripriming improves the germination and early seedling growth of rice (Oryza sativa L.). Journal of Soil Science and Plant Nutrition, v.34, p.1507-1515, 2011. www.tandfonline.com/doi/abs/10.1080/019041 67.2011 .585207

FERNANDEZ, I.C.D.; LUQUE, E.G.; MERCADO, F.G.; PEDROSA, W. Influence of temperature and salinity on the germination of Limonium tabernense Erben from Tabernas desert (Almeria SE Spain). Flora, v.218, p. 68-74, 2016. www.elsevier.com/locate/flora

GERM, M.; STIBILJ, V.; KREFT, I. Metabolic importance of selenium for plants. European Journal of Plant Science Biotechnology, v.1, p.91-97, 2007. www.globalsciencebooks.info/Online/GSBOnline/ images/.../EJPSB_1(1)91-97o.pdf

GOetTemoeller, J.; CHING, A. Seed germination in Stevia rebaudiana. In: JANICK, J. (eds). Perspectives on new crops and new uses. ASHS Press, Alexandria, VA, 1999. p.510-511.

HAJIHASHEMI, S.; EHSANPOUR, A.A. Antioxidant response of Stevia rebaudiana B. topolyethylene glycol and paclobutrazol treatments under In vitro culture. Applied Biochemistry and Biotechnology, v.172, p.4038-4052, 2014. www.ncbi.nlm.nih.gov/ pubmed/24604127

HSU, C.C.; CHEN, C.L.; CHEN, J.J.; SUNG, J.M. Accelerated aging enhanced lipid peroxidation in bitter gourd seeds and effects of priming and hot water soaking treatments. Scientia Horticulturae, v.98, p.201-212, 2003. www.sciencedirect.com/science/article/pii/ S0304423803000025
IBRAHIM EHAB, A. Seed priming to alleviate salinity stress in germinating seeds. Journal of Plant Physiology, v.192, p. 38-46, 2016. http://dx.doi.org/10.1016/j.jplph.2015.12.011

IQBAL, S.; FAROOQ, M.; NAWAZ, A.; REHMAN, A. Optimizing boron seed priming treatments for improving the germination and early seedling growth of wheat. Journal of Agriculture and Social Sciences, v.8, p.57-61, 2012. https://www.fspublishers.org/ published_papers/89239.pdf

JAMIL, M.; LEE, C.C.; REHMAN, S.U.; LEE, D.B.; ASHRAF, M.; RHA, E.S. Salinity $(\mathrm{NaCl})$ tolerance of Brassica species at germination and early seedling growth. Electronic Journal Environmental Agriculture Food Chemistry, v.4, p.273-282, 2005. https://jcea.agr.hr/articles/358_EFFECT_OF_SALT_(NACL)_ STRESS_ON_GERMINATION_AND_EARLY_SEEDLING_GROWTH_OF_FOUR_VEGETABLES_SPECIES_en.pdf

JAVADI, A.; KHOMARI, S.; SOFALIAN, O. Seed vigor and boron and calcium nutrition influence oilseed rape germinability and seedling growth under salt stress. Journal of Plant Nutrition,v.39, p.1688-1696, 2015. DOI: 10.1080/01904167.2015.1093138

JEZEK, P.; HLUŠEK, J.; LOŠAK, T.; JŮZL, M.; ELZNER, P.; KRAC̆MAR, S.; BUNKKA, F.; MARTENSSON, A. Effect of foliar application of selenium on the content of selected amino acids in potato tubers (Solanum tuberosum L.). Plant, Soil and Environment, v.57, p.315-320, 2011. www.agriculturejournals.cz/ publicFiles/43284.pdf

KHALIQ, A.; ASLAM, F.; MATLOOB, A.; HUSSAIN, S.; GENG, M.; WAHID, A.; REHMAN, H. Seed priming with Selenium: Consequences for emergence, seedling growth, and biochemical attributes of rice. Biological Trace Element Research, v.166, p.236244, 2015. link.springer.com/article/10.1007/s12011-015-0260-4

KHAN, R.; GURMANI, A.H.; GURMANI, A.R.; ZIA, M.S. Effect of boron application on rice yield under wheat rice system. International Journal of Agriculutre and Biology, v.8, p.805-808, 2006. https://www.fspublishers.org/published_papers/44772_..pdf

KUMAR-PAL, P.; PRASAD, R.; PATHANIA, V. Effect of decapitation and nutrient applications on shoot branching, yield and accumulation of secondary metabolites in leaves of Stevia rebaudiana Bertoni. Journal of Plant Physiology, v.170, p.1526-1535, 2013. www.ncbi. nlm.nih.gov/pubmed/23910992

LIN-DAI, Q.; CHEN, C.; FENG, B.; LIU, T.; TIAN, X.; GONG, Y.; SUN, Y.; WANG, J.; DU, S. Effects of different $\mathrm{NaCl}$ concentration on the antioxidant enzymes in oilseed rape (Brassica napus L.) seedlings. Plant Growth Regulation, v.59, n.3, p.273-278, 2009. link. springer.com/article/10.1007/s10725-009-9402-z

LIOPA-TSAKALIDI, A.; KASPIRIS, G.; SALAHAS, G.; BAROUCHAS, P. Effect of salicylic acid (SA) and gibberellic acid (GA, pre-soaking on seed germination of Stevia (Stevia rebaudiana) under salt stress. Journal of Medicinal Plants Research, v.6, p.416-423, 2012. www. academicjournals.org/journal/JMPR/article-abstract/992EB5719799

MACHADO NETO, N.B.; SATURNINO, S.M.; BOMFIM, D.C.; CUSTODIO, C.C. Water stress induced by mannitol and sodium chloride in soybean cultivars. Brazilian Archives of Biology and Technology, v.47, p.521-529, 2004. http://dx.doi.org/10.1590/S151689132004000400004 
MALAKOUTI, M.J.; KESHAVARZ, B.; KARIMIAN, N. A comprehensive approach towards identification of nutrient deficiencies and optimal fertilization for sustainable agriculture. Tarbiat Modarres, University Press, Tehran, Iran, p.755, 2009.

MATIAS, J.R.; RIBEIRO, R.C.; ARAGÃO, C.A.; ARAUJO, G.G.L.; DANTAS, B.F. Physiological changes in osmo and hydroprimed cucumber seeds germinated in biosaline water. Journal of Seed Science, v.37, n.1, p.7-15, 2015. http://dx.doi.org/10.1590/2317$1545 \mathrm{v} 37 \mathrm{n} 1135472$

McDONALD, M.B. Seed priming. In: BLACK, M.; BEWLEY, J.D. (ed.). Seed Technology and Biological Basis, Black, Sheffield Academic Press, England, 2000. p.287-325.

MEMON, N.N.; GANDAHI, M.B.; PAHOJA, V.M.; SHARIF, N. Response of seed priming with Boron on germination and seedling sprouts of Broccoli. International Journal of Agriculture Science and Research, v.3, n.2, p.183-194, 2013. https://www.researchgate. net/.../236663115_RESPONSE_OF_SEED_PRIMING_WITH

MIRSHEKARI, B. Effects of seed priming with micro elements of $\mathrm{Fe}$ and $\mathrm{B}$ on some germination parameters and yield of marigold (Calendula officinalis L.). Iranian Journal of Medicinal and Aromatic Plants, v.30, p.879-888, 2015. https://www.cabdirect.org/ cabdirect/abstract/20173173011

MOUHTARIDOU, G.N.; SOTIROPOULOS, T.E.; DIMASSI, K.N.; THERIOS, I.N. Effects of boron on growth, and chlorophyll and mineral contents of shoots of the apple rootstock MM 106 cultured in vitro. Biologia Plantarum, v.48, p.617-619, 2004. link.springer. com/article/10.1023/B:BIOP.0000047169.13304.67

NASRI, N.; SAIDI, I.; KADDOUR, R.; LACHAAL, M. Effect of salinity on germination, seedling growth and acid phosphatase activity in Lettuce. American Journal of Plant Science, v.6, p.57-63, 2014. http:// www.scirp.org/journal/ajpshttp://dx.doi.org/10.4236/ajps.2015.61007.

PAGTER, M.; BRAGATO, C.; MALAGOLI, M.; BRIX, H. Osmotic and ionic effects of $\mathrm{NaCl}$ and $\mathrm{Na}_{2} \mathrm{SO}_{4}$ salinity on Phragmites australis. Aquatic Botany, v.90, p.43-51, 2009. www.sciencedirect. com/science/article/pii/S0304377008000855

PAPARELLA, S.; ARAÚJO, S.S.; ROSSI, G.; WIJAYASINGHE, M.; CARBONERA, D.; BALESTRAZZI, A. Seed priming: state of the art and new perspectives. Plant Cell Reports, v.1, n.48, p.617619, 2015. https://www.ncbi.nlm.nih.gov/pubmed/25812837

PATADE, V.Y.; MAYA, K.; ZAKWAN, A. Seed priming mediated germination improvement and tolerance to subsequent exposure to cold and salt stress in Capsicum. Research Journal of Seed Science, v.4, p.125-36, 2011. docsdrive.com/pdfs/academicjournals/ rjss/2011/125-136.pdf

RAEESZADEH, M.; GHARINEH, M.H. Effects of gibberellic acid, nitric acid and moist chilling on seed germination Stevia. First International Congress and the Thirteenth National Congress of the Plant Breeding and Seed Science and Technology Conference. Tehran, v.4, p.1-4, 2014.

RAINA, R.; BHANDARI, S.K.; CHAND, R.; SHARMA, Y. Strategies to improve poor seed germination in Stevia rebaudiana, a low calorie sweetener. Journal of Medicinal Plants Research, v.7, p.17931799, 2013. www.academicjournals.org/article/article1380790733_ Raina\%20et\%20al.pdf
RAJI, A.A.; MOHAMMAD, B.O.; ZARINA, B.Z. Acclimatized apparatus enhanced seed germination in Stevia rebaudiana Bertoni. International Journal of Biology, v.7, p.28-34, 2015. www.ccsenet. org > Home > Vol 7, No 2 (2015)> Abdullateef

REHMAN, A.; FAROOQ, M.; CHEEMA, Z.A.; WAHID, A. Role of boron in leaf elongation and tillering dynamics in fine grain aromatic rice. Journal of Plant Nutrition, v.36, p.42-54, 2012. http://www. tandfonline.com/doi/abs/10.1080/01904167.2012.733048

ROUHI, H.R.; ABOUTALEBIAN, M.A.; SHARIF-ZADEH, F. Effects of hydro and osmopriming on drought stress tolerance during germination in four grass species. International Journal of AgriScience, v.1, p.107-114, 2011. https://www.sites.google.com/ site/inacjournals/home/int-j-of-agriscience

SAJEDI, N. Effect of hydropriming and priming with different concentration of selenium on yield and yield components of wheat. Iranian Journal of Field Crops Research, v.13, n.1, p.203-210, 2015. jcesc.um.ac.ir/index.php/arable/article/view/38757

SHAH, A.R.; ARA, N.; SHAFI, G. Seed priming with phosphorus increased germination and yield of okra. African Journal of Agricultural Research, v.6, n.16, p.3859-3876, 2011. http://www.academicjournals. org/article/article1380886125_Shah\%20et\%20al.pdf

SOLTANI, A.; GALESHI, S.; ZEINALI, E.; LATIFI, N. Germination, seed reserve utilization and seedling growth of chickpea as affected by salinity and seed size. Seed Science \& Technology, v.30, p.51-60, 2001. cat.inist.fr/?aModele $=$ afficheN\&cpsidt $=13659041$

TABATABAEI, S.J. Effects of salinity and $\mathrm{N}$ on the growth, photosynthesis and N status of olive (Olea europaea L.) trees. Scientia Horticulturae, v.108, n.4, p.432-438, 2006. www.sciencedirect.com/ science/article/pii/S030442380600094X

TABRIZIAN, F.; OSAREH, A.M. Improved seed emergence and yield related traits of marigold (Calendula officinalis L.) by on-farm seed micronutrient treatment trials. Iranian Journal of Crop Science, v.9, p.124-141, 2007. journals.areo.ir/article_11923.html

WANG, K.; ZHANG, L.; MEI, G.; LIXIA, L.; YONGGUI, Z.; LINSEN, Z.; BINZHI, L.; MINGYU, H.; ASHOK, K.A. Influence of salt stress on growth and antioxidant responses of two malus species at callus and plantlet stages. Pakistan Journal of Botany, v.45, n.2, p.375-381, 2013. www.pakbs.org/pjbot/PDFs/45(2)/04.pdf

YILDIRIM, E.; DURSUN, A.; GUVENC, I.; KUMLAY, A. The effects of different salt, biostimulant and temperature levels on seed germination of some vegetable species. Acta Agrobotânica, v.55, p.75-80, 2002. http://dx.doi.org/10.5586/aa.2002.045

YUN, X.; ZIJIAN, W.; PENG, A.W. Effect of selenium and fulvic acid on seed germination of wheat and its physiological properties. Chinese Journal of Applied Ecology, v.8, n.4, p.439-444, 1997. www.cjae.net/EN/abstract/abstract13297.shtml

ZHANG, J.; JIA, W.; YANG, J.; ISMAIl, A.M. Role of ABA in integrating plant responses to drought and salt stresses. Field Crops Research, v.97, p.111-119, 2006. www.sciencedirect.com/science/ article/pii/S0378429005002315 